\section{To: (Receiving Organization) \\ Distribution}

\section{Proj./Prog./Dept./Div.:}

Spent Nuclear Fuels Project

8. Originator Remarks:

For approval and release
3. From: (originating organization)

Engineering Development Laboratory / 8C922

6. Design Authority/ Design

J.J Irwin
Agent/Cog .Engr ::
11. Receiver Remarks: 11A. Design Baseline Document? [] Yes [X] No
4. Related EDT No.:
N/A
7. Purchase Order No.:
N/A

9. Equip./Component No.: $\mathrm{N} / \mathrm{A}$

10. System/Bldg./Facility:

CVD

12. Major Assm. Owg. No.: $N / A$

13. Permit/Permit Application No.: $N / A$

14. Required Response Date: $4 / 10 / 98$

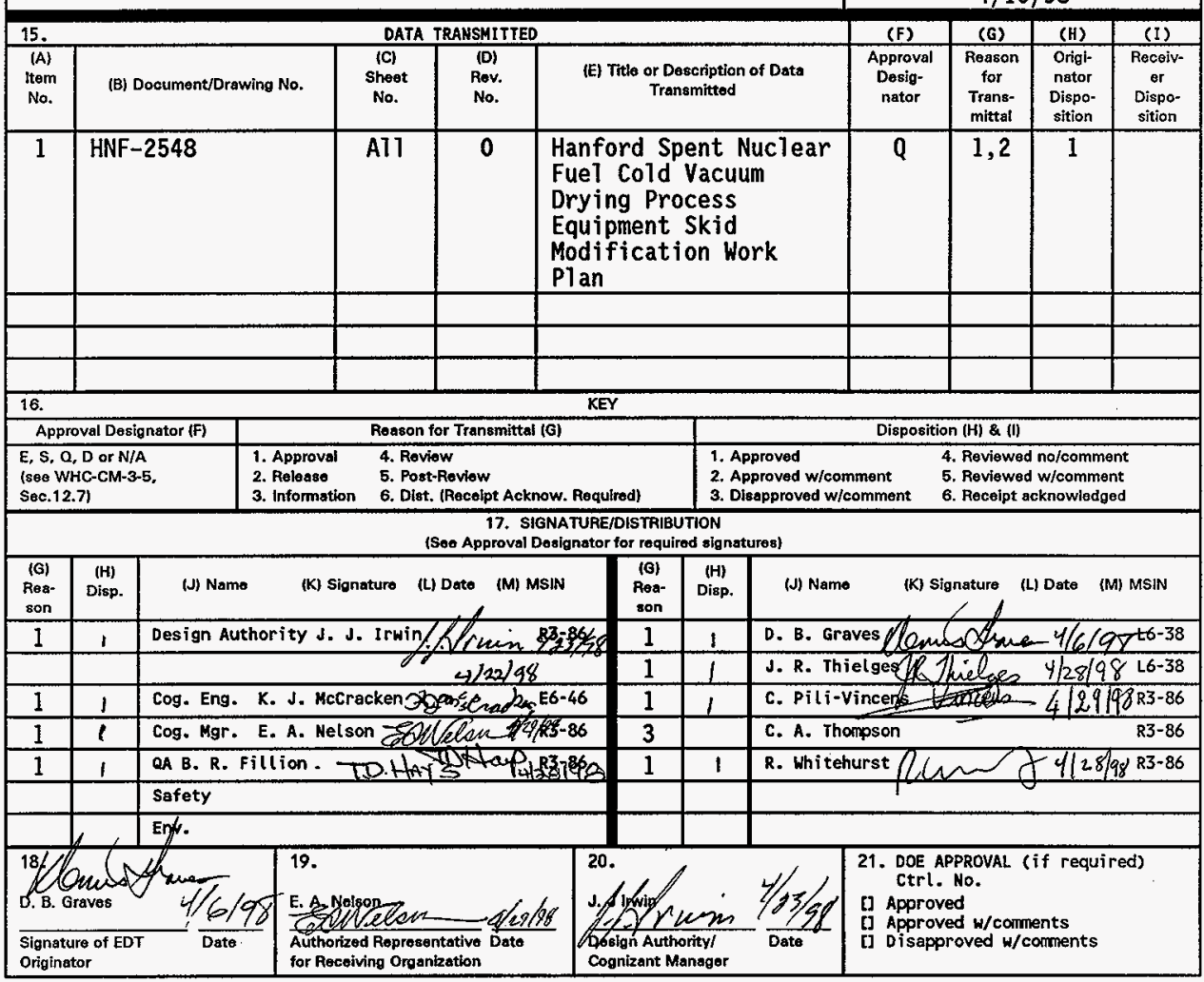




\section{Hanford Spent Nuclear Fuel Cold Vacuum Drying Process Equipment Skid Modification Work Plan}

Dennis B. Graves

COGEMA Engineering Corporation, Richland, WA 99352

Prepared for: Duke Engineering and Services Hanford.

U.S. Department of Energy Contract DE-AC06-96RL13200

$\begin{array}{ll}\text { EDT/ECN: } 606765 & \text { UC: } 510 \\ \text { Org Code: } 8 \text { C922 } & \text { Charge Code: LHFAT } \\ \text { B\&R Code: } 39 \text { SW704000 } & \text { Total. Pages: } 12 \text { ya }\end{array}$

Key Words: SPENT NUCLEAR FUEL, COLD VACUUM DRYING, PROCESS EQUIPMENT SKID, WORK PLAN, W-441-P1-FA

Abstract: This document provides the work plan for modifications to be made to the first article Process Equipment Skid for the Cold Vacuum Drying (CVD) process. The primary objective is to provide engineering configuration control for any modifications made to the Process Equipment Skid during proof of performance testing at the 306E Facility. "Development Control" procedures will be used to complete the design drawings and Procurement Specification W-441-P1-FA.

TRADEMARK DISCLAIMER. Reference herein to any specific commercial product, process, or service by trade name, trademark, manufacturer, or otherwise, does not necessarily constitute or imply its endorsement, recommendation, or favoring by the United States Government or any agency thereof or its contractors or subcontractors.

Printed in the United States of America. To obtain copies of this document, contact: Document Control Services, P.O. Box 950, Mailstop H6-08, Richland WA 99352, Phone (509) 372-2420; Fax (509) 376-4989.
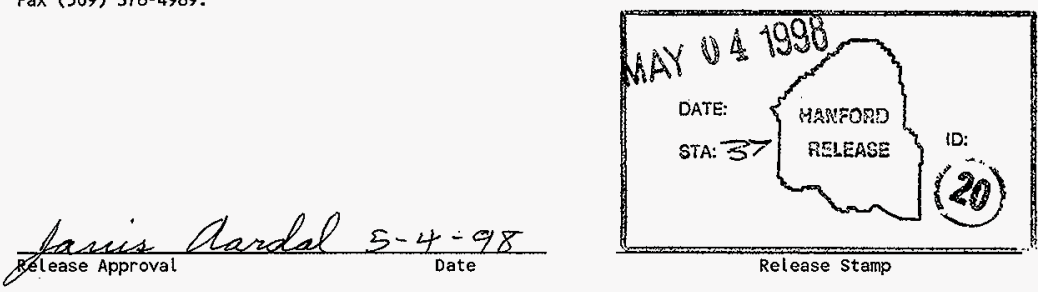
HNF-2548

Rev. 0

ENGINEERING REPORT

\title{
HANFORD SPENT NUCLEAR FUEL COLD VACUUM DRYING PROCESS EQUIPMENT SKID MODIFICATION WORK PLAN
}

Spent Nuclear Fuel Project (C56168/F2TH)

\author{
Prepared by \\ Numatec Hanford Corporation \\ P.O. Box 1300 \\ Richland, Washington \\ by
}

D. B. Graves, Principal Engineer

Engineering Development Laboratory, COGEMA Engineering Corporation

for

Duke Engineering Services Hanford Richland, Washington

Prepared by:

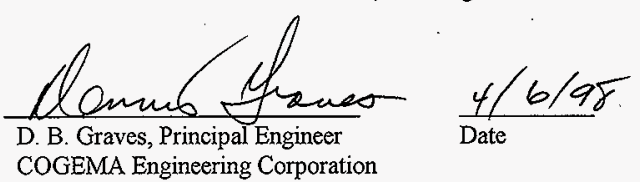

Fluor Daniel Northwest

Approved by: $228 a^{2}=e_{\text {nadem }}$

K. J. McCracken, Cognizant Engineer

Approved by:

$\frac{\text { T.D. Id amp }}{\text { T.D. Hays, Quality }}$

T. D. Hays, Quality Engineer $\frac{4 / 23 / 98}{\text { Date }}$

4130198

Date

Numatec Hanford Corporation

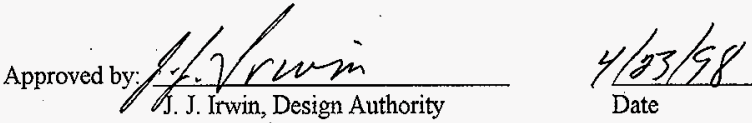


HNF-2548

Rev. 0

\section{INDEPENDENT REVIEW}

Document Reviewed Hanford Spent Nuclear Fuel Cold Vacuum Drying Work Plan

Author D. B. Graves_ Report No. HNF-2548 EDT No. $\underline{606765}$

The subject document has been reviewed by the undersigned. The reviewer reviewed and verified the following items as applicable [HNF-PRO-445].

- Engineering Specification

- Design Input

- Basic Assumption

- Approach/Design Methodology

- Related Information

- Conclusion/Result Interpretation

$\frac{228 \text { ors senotron }}{\text { Reviewer }}$

$4 / 28 / 98$

Date 


\section{TABLE OF CONTENTS}

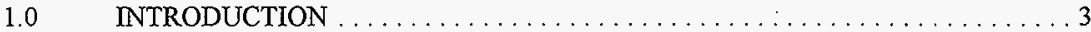

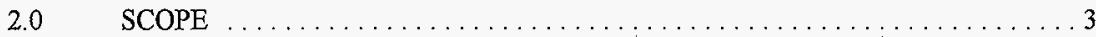

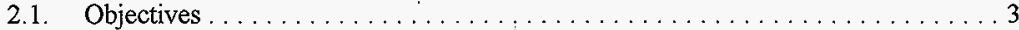

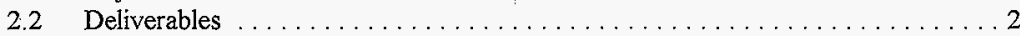

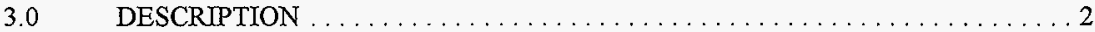

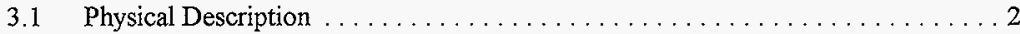

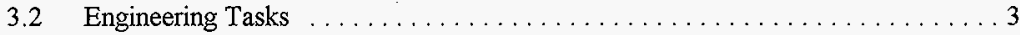

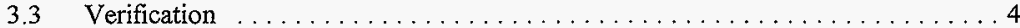

3.4 Procurement Tasks . . . . . . . . . . . . . . . . . . . . . . . . . . 4

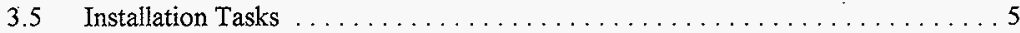

3.6 Pre-Operational and Operational Tests $\ldots \ldots \ldots \ldots \ldots \ldots \ldots \ldots \ldots \ldots$

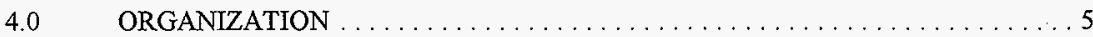

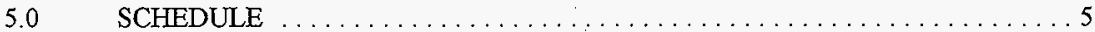

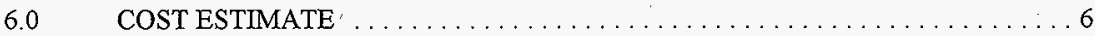

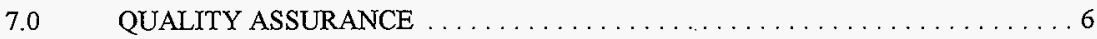

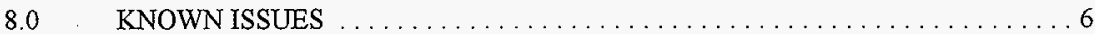

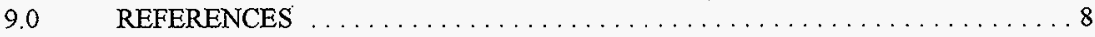

\section{LIST OF TABLES}

Table $1 \quad$ Process Equipment Skid Design Drawings $\ldots \ldots \ldots \ldots \ldots \ldots \ldots \ldots \ldots$

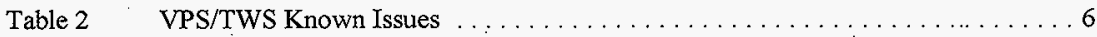




\subsection{INTRODUCTION}

This work plan is intended to support and control any modifications identified during supplier inspections and also identified during final first article Process Equipment Skid proof of performance testing. The necessary modifications concern items that require completion, rework, repair, replacement, and/or installation. These modifications were identified in non-conformance report (NCR) dispositions and other reports during supplier inspections. Additional reports will identify Process Equipment Skid hardware design changes necessary for operation generated by first article testing (HNF-2402). The Process Equipment Skid is a system for removing water and drying Spent Nuclear Fuel contained in Multi-Canister Overpacks. The skid contains the Vacuum Purge System and the Tempered Water System (VPS/TWS). The first article Process Equipment Skid, and subsequent production skids, will later be installed in the Cold Vacuum Drying Facility. Modifications will be controlled and documented using the Project Hanford "Development Control" process.

\subsection{SCOPE}

The initial "first article" Process Equipment Skid has been manufactured by a private vendor. The skid was manufactured, acceptance tested, and shipped in accordance with Procurement Specification W-441-P1-FA, Revision 1. The design drawings and procurement specification used for fabrication were based on the $90 \%$ design. However, a number of modifications were made during fabrication to respond to design review comments, to improve the design or to facilitate fabrication. At the completion of vendor acceptance testing, the design agent revised (but did not release) the procurement specification and design drawings to incorporate these changes and reflect as-built conditions when shipped from the vendor. In addition, there are planned modifications which have been deferred until proof of performance testing begins. These changes will be controlled by this work plan.

Proof of Performance testing will be conducted in accordance with HNF-SD-SNF-TP-036, "Hanford Spent Nuclear Fuel Cold Vacuum Drying Proof of Performance Test Specification and Test Plan", Revision 0. This work plan will insure configuration control of the first article Process Equipment Skid as required by HNF-PRO-442, "Development Control Requirements".

\subsection{Objectives}

The objective of this effort is to provide engineering control of the configuration of the first article Process Equipment Skid during proof of performance testing. The development control process will allow for engineering approval of any modifications and documentation of these changes. It allows the incorporation of planned modifications, design improvements and changes identified during testing. Released specifications and drawings will be provided by this effort, and they will be the basis for purchasing additional production skids. 


\subsection{Deliverables}

At the end of this development control task, performance testing will be complete, identified modifications will be made and all red line changes will be incorporated in the procurement specification and design drawings. The released as-built procurement specification and drawings are the final deliverables and will be approved and officially released as Revision 0 per HNF-PRO-317. Also, as required by the test plan HNF-SD-SNF-TP-036, a Design Modification Report will be prepared and released.

\subsection{DESCRIPTION}

\subsection{Physical Description}

The Process Equipment Skid is primarily a fully instrumented, self contained piping system. All system components and their configuration are defined by the design drawings and project authorized piping and instrumentation diagrams (P\&ID) listed in Table 1 and by Procurement Specification W-441-P1-FA, Revision 1. All equipment identified and assembled with these engineering documents will be under configuration control.

Table 1

Process Equipment Skid Design Drawings

\begin{tabular}{|c|c|l||}
\hline DRAWING NUMBER & SHEET & \multicolumn{1}{|c||}{ DRAWING TITLE } \\
\hline H-1-82160 & 1 & Cold Vacuum Drying Facility P\&ID Legend \\
\hline H-1-82161 & 1 & $\begin{array}{l}\text { Cold Vacuum Drying Facility Process Equipment Skid } \\
\text { P\&ID MCO/Cask Interface }\end{array}$ \\
\hline H-1-82162 & 1 & $\begin{array}{l}\text { Cold Vacuum Drying Facility Process Equipment Skid } \\
\text { P\&ID Vacuum Pumping System }\end{array}$ \\
\hline H-1-82163 & 1 & $\begin{array}{l}\text { Cold Vacuum Drying Facility Process Equipment Skid } \\
\text { P\&ID MCO/Temp Water System }\end{array}$ \\
\hline H-1-82164 & 1 & $\begin{array}{l}\text { Cold Vacuum Drying Facility Process Water } \\
\text { Conditioning P\&ID }\end{array}$ \\
\hline H-1-83770 & 1 & $\begin{array}{l}\text { Cold Vacuum Drying Facility Process System Schematic } \\
\text { First Article Test }\end{array}$ \\
\hline H-1-82354 & 1 & $\begin{array}{l}\text { Cold Vacuum Drying Facility Process Equipment Skid } \\
\text { Drawing List and Vicinity Map }\end{array}$ \\
\hline H-1-82354 & 2 & $\begin{array}{l}\text { Cold Vacuum Drying Facility Process Equipment Skid } \\
\text { Junction Box Assernbly }\end{array}$ \\
\hline H-1-82354 & 3 & $\begin{array}{l}\text { Cold Vacuum Drying Facility Process Equipment Skid } \\
\text { Connection Diagram }\end{array}$ \\
\hline
\end{tabular}


Rev. 0

Table 1

Process Equipment Skid Design Drawings

\begin{tabular}{|c|c|l||}
\hline DRAWING NUMBER & SHEET & \multicolumn{1}{|c|}{ DRAWING TITLE } \\
\hline H-1-82354 & 4 & $\begin{array}{l}\text { Cold Vacuum Drying Facility Process Equipment Skid } \\
\text { Connection Diagram }\end{array}$ \\
\hline H-1-82354 & 5 & $\begin{array}{l}\text { Cold Vacuum Drying Facility Process Equipment Skid } \\
\text { Structural }\end{array}$ \\
\hline H-1-82354 & 6 & $\begin{array}{l}\text { Cold Vacuum Drying Facility Process Equipment Skid } \\
\text { Structural Details }\end{array}$ \\
\hline H-1-82354 & 7 & $\begin{array}{l}\text { Cold Vacuum Drying Facility Process Equipment Skid } \\
\text { Condensate Tank VPS-TK-2116 }\end{array}$ \\
\hline H-1-82354 & 8 & $\begin{array}{l}\text { Cold Vacuum Drying Facility Process Equipment Skid } \\
\text { Recirc. Tank TW-TK-3212 }\end{array}$ \\
\hline H-1-82354 & 9 & $\begin{array}{l}\text { Cold Vacuum Drying Facility Process Equipment Skid } \\
\text { Piping Plan and Section }\end{array}$ \\
\hline H-1-82354 & 10 & $\begin{array}{l}\text { Cold Vacuum Drying Facility Process Equipment Skid } \\
\text { Piping Plan and Section }\end{array}$ \\
\hline H-1-82354 & 11 & $\begin{array}{l}\text { Cold Vacuum Drying Facility Process Equipment Skid } \\
\text { Piping Section and Details }\end{array}$ \\
\hline
\end{tabular}

\subsection{Engineering Tasks}

Procurement Specification W-441-P1-FA, Revision 1 and the design drawings listed in Table I will be placed under development control procedures as required by HNF-PRO-442. Requirements for equipment with facility-use potential will apply. An official copy of Procurement Specification W-441-P1-FA, Revision 1 and the design drawings listed in Table 1 will be maintained at the $306 \mathrm{E}$ facility where proof of performance testing will take place. Each page of the specification and drawings will be marked "DEVELOPMENT CONTROL" in red ink, signed and dated by the cognizant engineer. All changes, additions or deletions to the documents will be marked in red ink, or a sketch showing the changes will be attached to the appropriate page(s) of the document. Sketches will be marked to identify traceability to the original document. Changes and sketches will be approved, signed and dated next to each change by the cognizant engineer and the design authority. If necessary, a highly modified document page may be replaced with an updated page which includes all changes. The new page will be marked "DEVELOPMENT CONTROL", signed and dated as before. The original page will be retained until final QC and QA review. Engineering Change Notices (ECNs) will not be used. A log of each change which includes date, page number, revision number and general change description will be maintained. There will be one $\log$ for the procurement specification and one 
for the design drawing set. Development control documents and logs will be stored in a one hour minimum fireproof location when not in use for testing.

Modifications to the Process Equipment Skid will be performed by Equipment Development Laboratory (EDL) qualified personnel at the $306 \mathrm{E}$ facility. Modifications will be the same as shown on the development control (red-lined) documents, and will be performed under the direction of the cognizant engineer. When warranted by the complexity of the modification(s), or to document quality or nondestructive inspections; a fabrication traveler will be prepared per Operating Procedure OP-306-001 of WHC-IP-0550. The need for a traveler will be determined by the cognizant engineer, design authority, and the quality assurance engineer as governed by AP-11-002-00. The cognizant engineer, design authority and quality assurance engineer will approve each traveler.

Modifications will meet the applicable requirements defined in Procurement Specification W-441-P1-FA, Revision 1. Required retesting of systems after modifications shall be performed per the design requirements unless red-lined by the cognizant engineer and design authority. Retesting will be documented per the change control traveler and/or the Proof of Performance Test Specification, HNF-SD-SNF-TP-036.

At the completion of proof of performance testing and incorporation of all changes to the Process Equipment Skid, the red-lined documents will be submitted to the design authority and the design agent. The design authority will direct the design agent to incorporate all changes into the documents, obtain approval and release the documents as a new revision. The procurement specification will be modified, approved and released in accordance with HNF-PRO-241. Design drawings will be modified, approved and released in accordance with HNF-PRO-242.

\subsection{Verification}

After modifications are complete and the procurement specification and design drawings are prepared for approval; SNF Project Quality Control will verify that modifications to the Process Equipment Skid are the same as changes shown on the development control (red-line) documents. SNF Project $Q C$ will also verify that the final documents reflect all development control changes. Any discrepancies will be corrected under continued development control or by correction of the final documents. Nonconformance Reports are not required. After successful verification, Quality Control will prepare an "Accept Tag" for the Process Equipment Skid per HNF-PRO-297. Concurrence of the SNF Quality Assurance Engineer is required.

\subsection{Procurement Tasks}

Procurement of all materials necessary for modifications will be in accordance with established procurement guidelines. Safety Significant commercial grade items (CGI) will be procured in accordance with HNF-PRO-447. 


\subsection{Installation Tasks}

When modification and testing of the Process Equipment Skid is complete, the equipment will be repackaged in the original shipping containers or other containers approved by the design authority and cognizant engineer. Shipment from the $306 \mathrm{E}$ Building to the Cold Vacuum Drying Facility will be performed by Hanford Site Transportation Services. Installation of the Process Equipment Skid at the Cold Vacuum Drying Facility will be controlled by separate work planning prepared by the contractor for the Cold Vacuum Drying Facility.

\subsection{Pre-Operational and Operational Tests}

In-process testing of Process Equipment Skid components or systems that have been modified shall be completed per the design requirements unless redlined by the cognizant engineer and design authority. Acceptance testing of the Process Equipment Skid modifications will comply to the acceptance test requirements of Procurement Specification W-441-P1-FA, Revision 1, Section 6.0. When the Process Equipment Skid modifications are performed that can potentially change the results of previously performed proof of performance tests; retests will be approved, conducted and documented as required by Proof of Performance Test Specification HNF-SD-SNF-TP-036 utilizing the Proof of Performance Test Procedure HNF-2402.

\subsection{ORGANIZATION}

The primary authorities for this work plan are as follows:

$\begin{array}{ll}\text { Project Management } & \text { T. Choho / E. A. Nelson / A. H. McNeil } \\ \text { Design Authority } & \text { J. J. Irwin } \\ \text { Cognizant Engineer } & \text { K. J. McCracken / D. B. Graves } \\ \text { Test Director } & \text { K. J. McCracken } \\ \text { Test Facility Manager } & \text { J. R. Thielges } \\ \text { Quality Assurance } & \text { T. D. Hays } \\ \text { Quality Control } & \text { J. L. Walton } \\ \text { Design Agent } & \text { Merrick Engineers }\end{array}$

\subsection{SCHEDULE}

Work under this plan will be in parallel with proof of performance testing, with completion planned for mid July, 1998. 


\subsection{COST ESTIMATE}

Work activities are indefinite depending on the extent of modifications required. Funding will be on a time and materials basis. Funding of work activities is by TPCN LEFFAT.

\subsection{QUALITY ASSURANCE}

The majority of the equipment and systems on the Process Equipment Skid are classified as Safety Significant (SS), as defined by Safety Equipment List HNF-SD-SNF-SEL-002. Remaining portions of the Process Equipment Skid are classified General Service (GS). Applicable codes and standards for all equipment and processes are defined by Procurement Specification W-441-P1-FA Revision 1.

Quality assurance plans, criteria and requirements are defined by Manual DESH-1, Section 1.4, Attachment A, "Spent Nuclear Fuel Project Quality Assurance Program Plan", Revision 3.

DOE/RW/0333P, Quality Assurance Requirements and Description (QARD), is applicable for the activities related to temperature elements TE-3205 and TE-3212 as described in this work plan. This determination was made in accordance with HNF-1551, Rev. 0.

\subsection{KNOWN ISSUES}

Table 2 is a list of known items that require rework, repair, replacement, or installation based on NCRs and other reports issued against the Process Equipment Skid fabricated to W-441-P1-FA, Revision 1 that will be finalized with this work plan.

Table 2

VPS/TWS Known Issues

\begin{tabular}{||c|l|l|l||}
\hline \hline Item \# & $\begin{array}{l}\text { NCR \# or Report } \\
\text { Reference }\end{array}$ & Task Description & Timing \\
\hline 1 & \begin{tabular}{|c|l|l||} 
NCR 98-DESH-019 \\
Item 1
\end{tabular} & $\begin{array}{l}\text { MSLD leak test numerous flange and } \\
\text { mechanical systems that have been disturbed } \\
\text { after vendor final leak test. These lines include: }\end{array}$ & Prior to testing \\
\cline { 2 - 4 } & $\begin{array}{l}\text { PV-202-SS-1" } \\
\text { PV-201-SS-1" } \\
\text { VPS-201-SS-1" } \\
\text { VPS-202-SS-2" }\end{array}$ & $\begin{array}{l}\text { VPS-208-SS-2" } \\
\text { VPS-209-SS-1" } \\
\text { SMP-201-ST-1/4" } \\
\text { SMP-202-ST-1/4" }\end{array}$ & \\
\hline 2 & $\begin{array}{l}\text { NCR 98-DESH-019 } \\
\text { Item 3 }\end{array}$ & $\begin{array}{l}\text { Install OCRWM qualified instruments } \\
\text { (temperature elements TE-3205 and TE-3212) } \\
\text { and leak check per W-441-P1-FA, Revision 1 }\end{array}$ & $\begin{array}{l}\text { Prior to shipment to } \\
\text { CVDF }\end{array}$ \\
\hline \multirow{2}{*}{3} & $\begin{array}{l}\text { NCR 98-DESH-019 } \\
\text { Item 3 }\end{array}$ & $\begin{array}{l}\text { Vacuum pump commercial grade dedication or } \\
\text { evaluate and approve supplier }\end{array}$ & $\begin{array}{l}\text { Prior to shipment to } \\
\text { CVDF }\end{array}$ \\
\hline
\end{tabular}


Table 2

VPS/TWS Known Issues

\begin{tabular}{|c|c|c|c|c|}
\hline Item \# & $\begin{array}{l}\text { NCR \# or Report } \\
\text { Reference }\end{array}$ & \multicolumn{2}{|c|}{ Task Description } & Timing \\
\hline 4 & $\begin{array}{l}\text { NCR 98-DESH-019 } \\
\text { Item } 3\end{array}$ & \multicolumn{2}{|c|}{$\begin{array}{l}\text { Commercial grade dedications or approve and } \\
\text { evaluate suppliers for safety significant (SS) } \\
\text { items }\end{array}$} & $\begin{array}{l}\text { Prior to shipping to } \\
\text { CVDF }\end{array}$ \\
\hline 5 & $\begin{array}{l}\text { NCR 98-DESH-019 } \\
\text { Item } 4\end{array}$ & \multicolumn{2}{|c|}{$\begin{array}{l}\text { Install testing thermowells and temperature } \\
\text { probes and leak check per W-441-P1-FA, } \\
\text { Revision I }\end{array}$} & Prior to testing \\
\hline 6 & $\begin{array}{l}\text { NCR 98-DESH-019 } \\
\text { Item } 4\end{array}$ & \multicolumn{2}{|c|}{$\begin{array}{l}\text { Install qualified thermowells and temperature } \\
\text { probes and leak check per W- } 441-\mathrm{P} 1-\mathrm{FA} \text {, } \\
\text { Revision I }\end{array}$} & $\begin{array}{l}\text { Prior to shipping to } \\
\text { CVDF }\end{array}$ \\
\hline 7 & $\begin{array}{l}\text { NCR 98-DESH-019 } \\
\text { Item } 5\end{array}$ & \multicolumn{2}{|c|}{ HE-202-ST-1/4" impropetly located } & $\begin{array}{l}\text { Prior to shipment to } \\
\text { CVDF }\end{array}$ \\
\hline 8 & $\begin{array}{l}\text { NCR 98-DESH-019 } \\
\text { Item } 8\end{array}$ & \multicolumn{2}{|c|}{$\begin{array}{l}\text { Evaluate pump VPS-P-2205 and VPS-P-2206 } \\
\text { and associated connections hose connections } \\
\text { after installation. (See Item 14.) }\end{array}$} & $\begin{array}{l}\text { Prior to shipping to } \\
\text { CVDF }\end{array}$ \\
\hline 9 & $\begin{array}{l}\text { NCR 98-DESH-019 } \\
\text { Item } 9 \text {. }\end{array}$ & \multicolumn{2}{|c|}{ General system cleanliness verification } & Prior to testing \\
\hline 10 & $\begin{array}{l}\text { NCR 98-DESH-030 } \\
\text { Item } 3\end{array}$ & \multicolumn{2}{|c|}{$\begin{array}{l}\text { Provide vessel tagging and labeling } \\
\text { identification }\end{array}$} & $\begin{array}{l}\text { Prior to shipping to } \\
\text { CVDF }\end{array}$ \\
\hline 11 & $\begin{array}{l}\text { NCR 98-DESH-030 } \\
\text { Item } 4\end{array}$ & \multicolumn{2}{|c|}{$\begin{array}{l}\text { Provide tagging and labeling per project } \\
\text { labeling method }\end{array}$} & $\begin{array}{l}\text { Prior to shipping to } \\
\text { CVDF }\end{array}$ \\
\hline 12 & Project Direction & \multicolumn{2}{|c|}{ Location of IA-V-2022 } & As required to test \\
\hline 13 & Project Direction & \multicolumn{2}{|c|}{ Install RGA AE-2213 and sample lines } & As required to test \\
\hline 14 & Project Direction & \multicolumn{2}{|c|}{$\begin{array}{l}\text { Install Helium recirculation pumps } \\
\text { VPS-P-2205 and VPS-P-2206 and associated } \\
\text { connections }\end{array}$} & As required to test \\
\hline 15 & Project Direction & \multicolumn{2}{|c|}{ Install He-204-ST-1/4" and He-V-2063 } & Prior to testing \\
\hline 16 & Project Direction & \multicolumn{2}{|l|}{ Install PCV-1226 } & Prior to testing \\
\hline 17 & Project Direction & \multicolumn{2}{|c|}{ Install He-V-2016 and He-CKV:2067 } & $\begin{array}{l}\text { Prior to shipping to } \\
\text { CVDF }\end{array}$ \\
\hline \multirow[t]{2}{*}{18} & \multirow[t]{2}{*}{ Project Direction } & \multicolumn{2}{|c|}{$\begin{array}{l}\text { Leak test (per W-441-PI-FA, Revision I) the } \\
\text { following lines, as applicable: }\end{array}$} & Prior to testing \\
\hline & & $\begin{array}{l}\text { TW-201-SS-1 1/2" } \\
\text { TW-202-SS-1 1/2" } \\
\text { TW-208-SS-1" } \\
\text { VPSCHW-202-SS-1" } \\
\text { PV-202-SS-1" } \\
\text { PV-201-SS-1" } \\
\text { VPS-201-SS-1" } \\
\text { VPS-202-SS-2" }\end{array}$ & $\begin{array}{l}\text { VPSCHW-203-SS-1" } \\
\text { IA-201-SS-1" } \\
\text { IA-202-ST-1/4" } \\
\text { IA-203-SS-1" } \\
\text { VPS-208-SS-2" } \\
\text { VPS-209-SS-1" } \\
\text { SMP-201-ST-1/4" } \\
\text { SMP-202-ST-1/4" }\end{array}$ & \\
\hline
\end{tabular}


Additional items, later identified throughout the first article testing program, shall be modified in accordance with this work plan.

\subsection{REFERENCES}

DOE, Quality Assurance Requirements and Description, DOE/RW-0333P, Office of Civilian Radioactive Waste Management, U.S. Department of Energy, Washington D.C.

HNF, Cold Vacuum Drying Facility OCRWM Requirements, HNF-1551, Revision 0, Hanford, Richland, Washington.

W-441-P1-FA, Revision 1, Procurement Specification for the Fabrication, Acceptance Testing, and Shipment of the Cold Vacuum Drying System First Article Process Equipment Skid, April 1998, Hanford, Richland, Washington.

HNF, Hanford Spent Nuclear Fuel Cold Vacuum Drying Proof of Performance Test Specification and Test Plan, HNF-SD-SNF-TP-036, Revision 0, Cannon et al, February 1998, Hanford, Richland, Washington.

HNF, Safety Equipment List, HNF-SD-SNF-SEL-002, Revision 1, Irwin, March 1998, Hanford, Richland, Washington.

HNF, 306E Facility Equipment Operating Procedures, Manual WHC-IP-0550, Hanford, Richland, Washington.

HNF, Spent Nuclear Fuel Project Quality Assurance Program Plan, Manual DESH-1, Section 1.4, Attachment A, Revision 3, Hanford, Richland, Washington.

HNF, Engineering Specification Requirements, HNF-PRO-241, Hanford, Richland, Washington. HNF, Engineering Drawing Requirements, HNF-PRO-242, Hanford, Richland, Washington.

HNF, Engineering Release and Approval Requirements, HNF-PRO-317, Hanford, Richland, Washington.

HNF, Development Control Requirements, HNF-PRO-442, Hanford, Richland, Washington.

HNF, Procurement of Safety Class Items and Management of Spares, HNF-PRO-442, Hanford, Richland, Washington.

HNF, Hanford Spent Nuclear Fuel Cold Vacuum Drying Proof of Performance Test Procedure, HNF-2402, Hanford, Richland, Washington.

SNF, Spent Nuclear Fuel Quality Assurance Inprocess and Final Inspection, Administrative Procedure, AP-11-002-00, Hanford, Richland, Washington. 


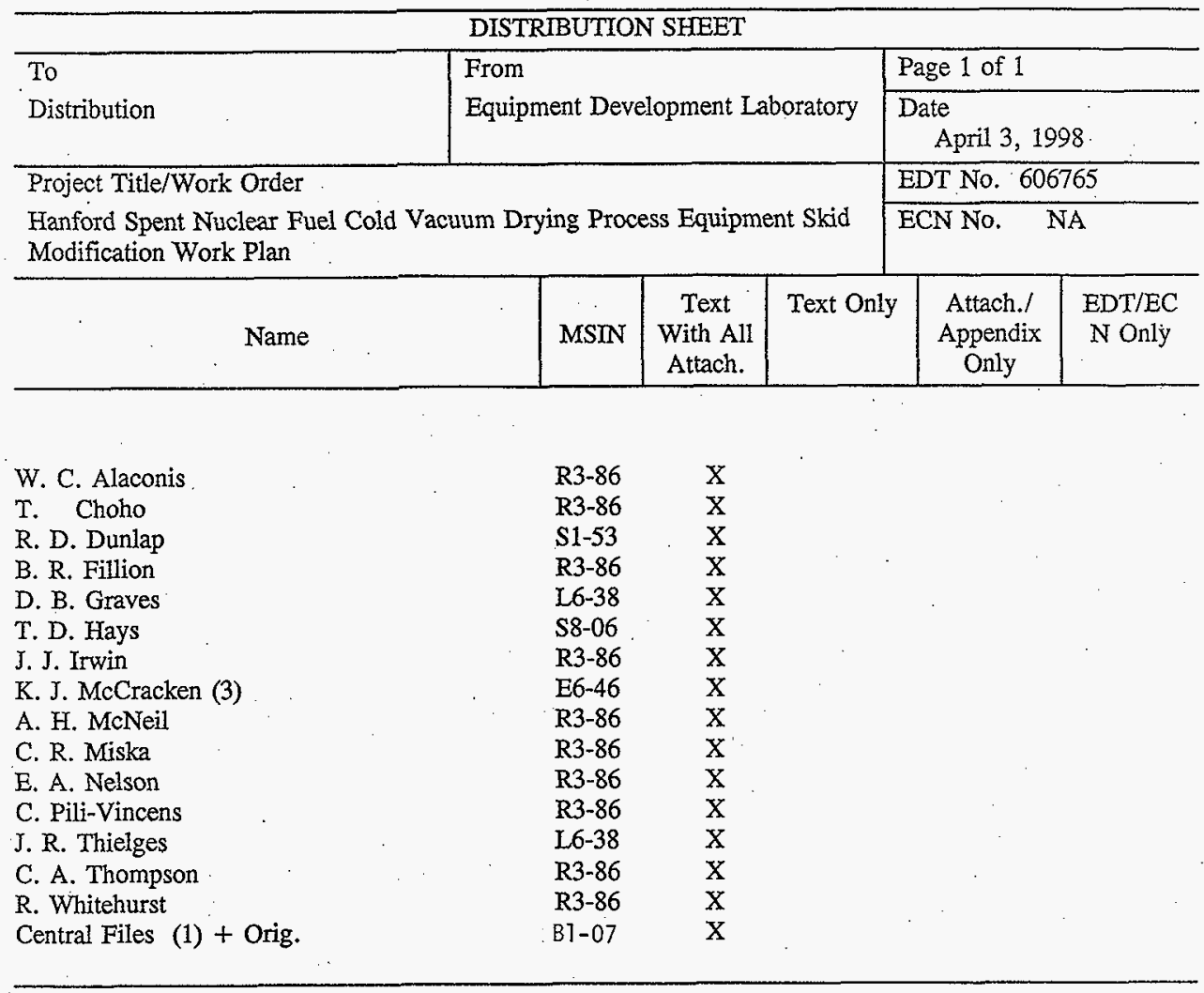

